\title{
Awareness and Preventions of Malaria in Pregnant Women: A Study of
} Mile Four Hospital, Nigeria

\author{
Article by Mgbe Chinenye $\mathrm{G}^{1}$, Mgbe Emeka Kevin ${ }^{2}$, Rita Uzoamaka Nwali ${ }^{3}$ \\ ${ }^{1}$ Ph.D, Enugu State University Teaching Hospital \\ ${ }^{2} M B B S$, fWACS, University of Nigeria Teaching Hospital Ituku \\ ${ }^{3}$ B.sc, Department of Public Health, National Open University of Nigeria \\ E-mail: chinenyemgbe@yahoo.com ${ }^{1}$, champlinks2001@yahoo.com ${ }^{2}$
}

\begin{abstract}
This cross sectional study was conducted at the maternity unit of Mile Four Hospital in Abakaliki Ebonyi State. The aim was to determine the degree of awareness and practice of malaria prevention strategies among antenatal attendees in Mile Four Hospital in Abakaliki Ebonyi State. Semistructured questionnaires were administered to one thousand five hundred and sixteen pregnant women in the antenatal clinic. The findings revealed among other things that pregnant women attending antenatal clinic in Mile Four Hospital Abakaliki in Ebonyi State are aware of malaria preventive measures and are utilizing malaria preventive measures to prevent themselves. The study recommended among other things that, awareness campaign should be drawn to rural areas so that Pregnant women should be educate on high risk involve in malaria infestation for total eradication of miscarriage, low birth weight, still birth and maternal death.
\end{abstract}

Keywords: Awareness, Malaria, Prevention, pregnant women.

\section{Introduction}

Malaria is a mosquito- borne diseases of humans and other animals cause by parasitic protozoan of the genus plasmodium. It is transmitted through the bite of an infected anopheles mosquito. According to (WHO), an estimated 214 million new cases occurred word wide in 205 and 438,000 malaria deaths with the African region accounting for most global cases of malaria (88\%). Malaria in pregnancy is an immense public health problem.

Currently, it is estimated that each year more 125 million women become pregnant in malaria epidemic areas in the word with 30 million of this in sub-sahara Africa, and that 75, 000- 200, 000 infants deaths are attributed to malaria infection in pregnancy, report show that the burden of malaria in pregnancy in Nigeria is high. $100 \%$ of women who had no prophylaxis is experienced attacks of malaria, with $76 \%$ experiencing two more attacks. Ahmed et al; (2010). 51\% pregnant women surveyed using aremsa staining were positive for malaria infection (Chukwuocha et al.; 2001). Pregnant women are more likely than non- pregnant women to become infected with plasmodium falciparum and once infected, there is a tendency towards increased severity of disease caused in part by the transient depression of cells mediated immunity that occurs during pregnancy. Under conditions of high transmission, there is increased plasmodium falciparum parasite density in placenta and peripheral blood, which is higher in first, compared to later pregnancies. This epidemiological pattern for plasmodium falciparum has been recognized for several years, with higher density in early pregnancy, which increases in untreated, and then decreased as gestation progresses in stable high transmission areas, almost primigravidae if unprotected, are likely to be infected in early pregnancy and approximately, half of these would remain so by the time of delivery if untreated. In multigravidea, especially in those with high parities, parasites are significantly reduced due to the acquisition of parity-specific immunity.

This potential fetal infection must be prevented but when they develop, they require prompt diagnosis and treatment. The most harmful effect on the mother is caused by plasmodium falciparum. In areas of high transmission, severe anaemia is common and associated with high mortality, where as 
ISSN: $2520-3134$

in areas of low transmission or in epidemics, pregnant women are at risk of high severe cerebral malaria and death (David Sinclair, 2012).

Millions of pregnant women are exposed to malaria and thousands die every year as direct or indirect consequences. (WHO, 2010). It further stated that in all endemic areas, babies born to mothers infected with malaria parasites have a low birth weight and also at increased risk of death in infancy. Therefore, it is essential to treat pregnant women, who are infected with plasmodium parasites effectively (Bugvi et al.; 2015). Unfortunately, a cheap, safe and effective drug such as chloroquine has globally lost its efficacy against malaria parasites (plasmodium falciparum). Malaria is highly endemic in Nigeria and possesses a major challenge to human development (Williams, 2016).

It is both the cause and consequences of under-developed and also remains one of the leading cause of morbidity and mortality in the country David Sinclair (2012). It accounts for about $60 \%$ of all clinic attendance in the country (WHO, 2010). The most vulnerable groups are children below five years of age and pregnant women primigraividae. in Nigeria, the situation of antenatal care ascertained during the baseline data collection for monitoring and revaluating roll back malaria (RBM) showed that on the average, $68.6 \%$ of pregnant women in the current pregnancy were receiving care and mostly in rural health centre (White et al.; 2014)

Furthermore, malaria is responsible for $25 \%$ of infant mortality and $30 \%$ of all childhood death and that is why Nigeria is a signatory to the Abuja declaration that set as one of the Abuja targets that $60 \%$ of pregnant women should receive intermittent preventive treatment drug during pregnancy by end of 2005 (WHO, 2010). Despite the effective launching of the roll back malaria since year 2001 in most African countries, pregnant women and their unborn babies continue to face disproportionate high burden of the disease. Pregnant women have a higher risk than the non - pregnant ones to be infected with malaria and they are at increased risk of adverse events such as anaemia, risk of miscarriage, still birth, preterm delivery, total growth, restriction and even death.

Preventing severe anaemia caused by malaria in pregnancy will head to fewer pregnant women requiring blood transfusion thereby reducing the risk of transfusion related infections especially HIV and Hepatitis B. adequate control of malaria in pregnancy will improve survival of mother and reduce prenatal mortality.

Malaria which is described as a febrile illness (WHO, 2003) can affect everyone, but pregnant women are known to have high risk for the disease with grievous consequences, malaria during pregnancy is accountable for an approximately $11 \%$ of maternal morbidity in Nigeria (United States Embassy in Nigeria, 2011) despite the awareness and high development World health organization (2013) observed that they was lack of adequate knowledge of malaria especially in regions where the prevalence of the disease is high.

Knowledge is one of the important elements in any effort targeted towards the reduction of disease burden such as malaria (Minnesota Health Acrim Team, 2010) (Ducarme et al.; 2008) reported that the failure to establish the level of knowledge of community members regarding malaria appeared to be responsible for the mobility of intervention programmes to achieve suitable control. Consequently every women is expected to possess an appreciable level of knowledge of the cause, breeding sources, mode of transmission, consequences and prevention for successful eradicative of the disease in any given community. This is because women have been recognized as the closest members of the family responsible for health care of the children and other members of the family. It is therefore necessary for women to posses' adequate knowledge about disease including malaria in order to protect members from the scourge of the disease.

Most Ebonyi people including women and highly involve in agricultural activities, which encourage the breeding of mosquitoes and consequently malaria infection is not an over statement to state that malaria has numerous negative outcomes which may include financial involvement translating into poor standard of living, hospital visitations as well as low productivity and loss of income (Kayentao et al.; 2005) sequel to this, the Ebonyi state in collaboration with Roll Back Malaria (RBM) in February 2011 took positive steps to reduce the spread of malaria in the state.

The action involved house distribution of Insecticide Treated Net (ITN) to mothers. However, after the distribution of the nets, a casual discussion with some of recipients revealed that the act of 


\section{Texila International Journal of Public Health}

Volume 6, Issue 2, Jun 2018

distributing the net was seen as a political programmes, and nets where seen as a gift from politician rather that a malaria prevention venture. A few of discussants also indicated they would keep the nets until rainy season before using them. The observation made on then women tend to suggest a possible gap in malaria knowledge

However, malaria in pregnancy is an obstetric social and medical problem requiring multidisciplinary and multidimensional solution (WHO, 2013) malaria the most dangerous human parasitic disease, is both preventable and treatable but continues to kill inappropriately, especially children and pregnant women. In all malaria evidence areas, infection by any human plasmodium specie during pregnancy is detrimental to the mother and the foetus.

Finally, malaria is still a public health concern particularly in sub-Sahara Africa and other parts of the developing world, (Bhatia et al.; 2013).

\section{Statement of the problem}

According to the world health organization (WHO, 2010) a quarter of all malaria cases in Africa occurs in Nigeria. This magnitude of occurrence in this part of the world correlates with poverty, ignorant and social deprivations in the community. The problems of malaria in pregnancy possess a substantial risk to the mother, her fetus and the neonates. It significantly contributes to anaemia in pregnancy as the parasitmia appear greater in the second trimester and may persist into the early postpartum period, increasing the low birth weight and is associated with preterm deliveries, still birth and perinatal mortality in Nigeria .(Centre for Disease and Prevention, 2009).

A researcher during his research in Federal Teaching Hospital Abakaliki observed that the pregnant women attending antenatal in that hospital, were always falling sick and as much come to the clinic before their appointment dates. Moreover, malaria in pregnancy was the worst occurring medical diagnosis in the medical records department of the hospital. The situation mentioned above raised the researcher's curiosity on the awareness and utilization of malaria preventive measures to pregnant women, attending antenatal clinic in order to join the way forward to provide a better pregnancy outcome, improve the survival of the mother and reduce prenatal mortality.

\section{Purpose of the study}

The broad purpose of the study is to determine the degree of awareness and practice of malaria prevention strategies among antenatal attendees in Mile Four Hospital in Abakaliki Ebonyi State.

\section{Research questions}

1. What are the challenges in the awareness of malaria preventive measures to pregnant women, attending antenatal clinic in Mile Four Hospital, Abakaliki in Ebonyi State?

2. What are the challenges of utilization of malaria preventive measures to pregnant women, attending antenatal clinic in Mile Four Hospital, Abakaliki in Ebonyi State?

\section{Significance of the study}

The study will create awareness on the causes, prevention, treatment and implication of malaria in pregnancy among the clients, public health students, communities and the society at large thereby reducing the financial burden and mortality resulting from malaria in pregnancy in the state and beyond.

It will provide information on adequate protection from mosquito bite especially during pregnancy to prevent malaria attack and its advance effects. It will also form basic for reference to other researchers who might work on the subject matter as well as mile four hospital management to design strategies for reducing malaria among their pregnant clients.

The findings will also help to improve the epidemiological data of the state ministry of health and consequently, help in further intervention plan in malaria prevention in the state. Furthermore, the data so generated will attract the attention of donor agencies as it will serve as assessment of the intervention strategies on the ground. 
DOI: $10.21522 /$ TIJPH.2013.06.02.Art014

ISSN: $2520-3134$

\section{Limitation of the study}

This study was adversely affected by a number of factors. The researcher faced with time constraints, due to the fact that this type of study requires long period of time to gather data. It was not at the disposal of the researcher as the some project audience falsified data and out rightly refused to participate in the study. Other limitations include, lack of fund and difficulty in volunteering information. However, these constraints did not stop the success of the study.

\section{Literature review}

\section{Concept of malaria}

Malaria, a life threaten parasitic disease has been known since time immemorial. Previously, it was thought that "miasma" (bad air gas from swamps) causes malaria this and a host of others are the misconceptions that many theorists have about malaria.

Malaria is a life threatening parasite disease transmitted by the female anopheles mosquitoes. Malaria is the most highly prevalent tropical disease, with high morbidity and mortality as well as high economic and social impact (WHO, 2001).

According to (WHO, 2003) malaria remains one of the most important threat to the health of pregnant women and their new born. In fact, its control is one of the most challenging in Africa where 45 countries including Nigeria are endemic for malaria and about 588 million people are at risk (WHO, 2003). The protection of women living in malaria endemic countries has been of peculiar interest to many National Malaria Control Programmes because of their reduced immunity.

This is not unconnected to the fact that malaria during pregnancy presents a unique problem. Pregnant women are at high risk of developing severe and fatal malaria because normal immune responses are reduced during pregnancy.

Today, approximately $40 \%$ of the world's population mostly those living in the world's poorest countries. Is at risk of malaria, on the average, each Nigeria suffers at least two or more attacks every year and while millions recover, hundreds or thousands are not so lucky. This single disease accounts for about $60 \%$ of outpatient visits, $30 \%$ hospitalizes, $25 \%$ of death in children under one year old, and $11 \%$ of maternal death a heavy burden of Nigerian families, communities, health system and workforce (WHO, 2013).

Although, malaria control efforts have helped reduce the global malaria burden, most malaria endemic countries are now meeting whose target for malaria control. Nigeria is amongst the five most malaria endemic countries in Africa alongside the Democratic Republic of Congo, Ethiopia, Kenya and Tanzania. Together, they account for more than half of the continents burden. While interventions have helped reduced malaria cases and death, less than $50 \%$ of people at risk have access to insecticide treated nets (ITN) last year, the number of ITNs distributed to national malaria control programme has also improved but the race is far from over to ensure that the country will meet WHO'S target of $80 \%$ coverage for the four main malaria treatments: ITNs, artemisinni - based combination therapies, indoor insecticides spraying programmes and treatment of pregnant women.

Desai et al; (2015) has declared malaria as being burdensome over several decades and still remains a burden especially for population in the endemic areas of the world. The authors noted that; "unfortunately, Africa is a known centre for malaria but tropical Africa that is, sub-Sahara seems to be at the receiving end of the malaria burden. infact, you can imagine the number of deaths recorded yearly from the under-five and even pregnant women.

\section{Life cycle of malaria parasite in nigeria}

The malaria parasite, plasmodium is very small single cell blood organism or protozoan. It lives as a parasite in other organisms, namely man and mosquito. The plasmodium parasite is dependent on a single species of mosquito, anopheles, which is the only species capable of serving as the host of it (Ducarme, 2008).

Diagram of life cycle of plasmodium vivax in man and the mosquito 


\section{Texila International Journal of Public Health \\ Volume 6, Issue 2, Jun 2018}

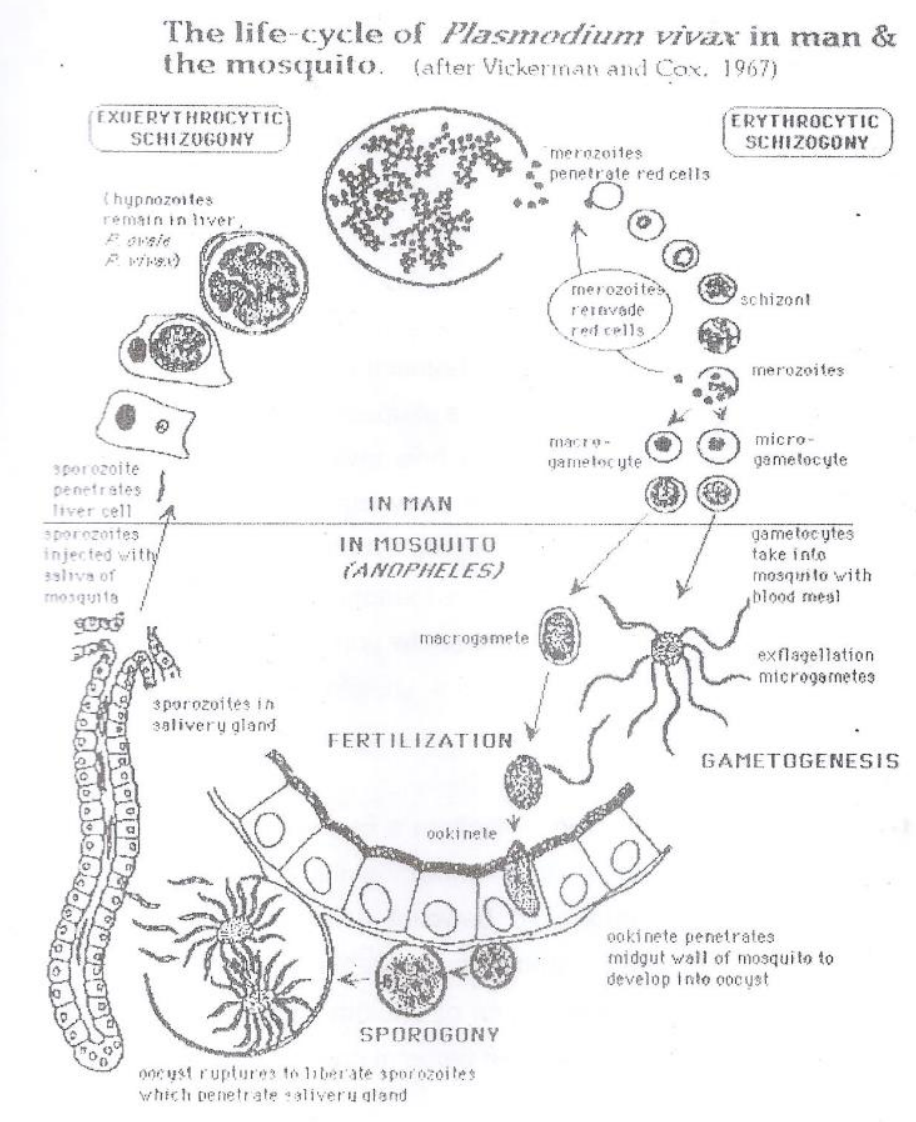

Animation: Lifecycle of a malaria parasite from mosquito to blood stages

The different stages of the parasite Life cycle from the diagram:

a. Mosquito infected with malaria parasite bites human, passing cell called "sporozoites" into the human blood stream.

b. Sporozoites travel to deliver

c. Merozoites enters the blood stream and infect Red Blood Cells

d. In Red Blood Cell merozoites grow and divide to produce more merozoites, eventually causing the Red Blood Cell rupture.

\section{Methodology}

\section{Research design}

The study employed a cross sectional research design to ascertain the extent of awareness and utilization of malaria preventive measures to pregnant women, attending antenatal clinic.

A structured interviewer- self-administered survey questionnaire was used to the selected staff and women attending to antenatal at Mile Four Hospital

\section{Area of the study}

The study was conducted in antenatal section of Mile Four Hospital Abakaliki Ebonyi State. The Hospital is located along old Abakaliki Enugu Road, Ebonyi State. 
DOI: $10.21522 /$ TIJPH.2013.06.02.Art014

ISSN: $2520-3134$

\section{Population of the study}

The study population includes all the staff of antenatal section and pregnant women attending antenatal in Mile Four Hospital Abakaliki. A simple random sample of one thousand five hundred and sixteen $(1,516)$.

Table 1.Total number of staff in Antenatal section and pregnant women attending Antenatal in Mile Four Hospital, Abakaliki

Source: (survey, 2016).

\begin{tabular}{|l|l|l|}
\hline Grade Level & Total & Percentage \\
\hline Senior Cadre & 45 & $3 \%$ \\
\hline Junior Cadre & 51 & $4 \%$ \\
\hline Women attending Antenatal: & & \\
\hline Zero Months - 5 Months & 870 & $57 \%$ \\
\hline 7 Months - 9 Months & 550 & $36 \%$ \\
\hline Total & 1,516 & $100 \%$ \\
\hline
\end{tabular}

\section{Sampling technique}

The simple random sampling technique was used in this study. A situation where respondent were randomly selected so that every members of the population is equal and has independent chance of being selected in the sample to study.

\section{Instrument of data collection}

The major instrument that the researcher used for collection of data was structured questionnaires to elicit and generate information concerning the topic investigated. The researcher visited Mile Four Hospital to distribute the questionnaire personally. Respondents were given four options of strongly agree (SA), agree (A), strongly disagree (SD) and disagree (D) to ascertain the degree of acceptance or rejection of the views expressed by the questionnaire.

\section{Tests for validity}

Validity is defined as the degree to which a measuring instrument measures what it is designed to measure given that every measuring instrument is designed for a specific measurement (Asika, 1991). It also refers to the authentic nature of the measuring instrument in being capable of eliciting the necessary information applicable to the study. In order to ascertain the validity of the instrument, it was subjected to face validation and content validity. The structured questionnaire was vetted by the project supervisor and other experts in the field understudy. Corrections were effected; the instrument was fine tuned to measure exactly what it intends to measure. The researcher was guided strictly by the corrections and adjustment made. Hence, the instrument was considered appropriate for the study.

\section{Method of data analysis}

The data collected for the study were first arranged in table containing the number of respondents and the corresponding percentages of the responses. This was done for easy understanding of the analysis of the tables. The hypotheses formulated for the study were tested using $\mathrm{Z}$ statistics.

$\mathrm{Z}$-value is a test statistic for Z-tests that measure the difference between an observed statistic and its hypothesized population parameter in units of the standard deviation.

The formular is given as:

$$
Z=\frac{\pi-\mu}{\mathbf{S} / \sqrt{\mathbf{n}}}
$$

Where $\mathrm{Z}=\mathrm{Z}$-value 
$\pi=$ Mean Sample

$\mathrm{S}=$ Sample standard deviate

$\mathrm{n}=$ Number of the Respondents

\section{Results}

These deals with the presentation of data collected from Mile Four Hospital Abakaliki, the respondent were grouped into two which includes: Senior and Junior Cadres. For proper analysis, the data was presented with the aid of table percentage. Table below details the questionnaire distributed to the respondents.

Table 2. Number of questionnaire distributed and number of questionnaire returned

\begin{tabular}{|l|l|l|l|}
\hline Staff Grade level & $\begin{array}{l}\text { Number of } \\
\text { distributed }\end{array}$ & Number of returned & \% returned \\
\hline Senior Cadre & 45 & 45 & $12 \%$ \\
\hline Junior Cadre & 51 & 51 & $13 \%$ \\
\hline Zero - 5Months & 154 & 148 & 37 \\
\hline 6-9 Months & 150 & 144 & 36 \\
\hline Total & 400 & 388 & 98 \\
\hline
\end{tabular}

Source: Field survey november, 2015.

The above table 2 shows that four hundred questionnaires were distributed to the respondents, out of the 400 questionnaires, 45 representing $12 \%$ were administered to the senior staff, 51 questionnaires representing $13 \%$ were also distributed to junior staff, and the entire questionnaire were returned completely. Moreover, 154 questionnaires were also distributed to Pregnant Women attending antenatal from 0-5 months and 150 questionnaires were also distributed to Pregnant Women attending antenatal from 6- 9 months and 148 and 144 were returned respectively. Therefore, out of 400 questionnaires distributed to the staff and pregnant women, 388 questionnaires representing 98\% of the total questionnaires were returned.

Question: Mosquitoes bite causes malaria

Table 3. Responds on whether mosquitoes bite causes malaria

\begin{tabular}{|l|l|l|}
\hline Responses & $\begin{array}{l}\text { No of } \\
\text { Respondents }\end{array}$ & \% of Respondents \\
\hline Strongly Agreed & 215 & $55 \%$ \\
\hline Agreed & 154 & $40 \%$ \\
\hline Strongly Disagreed & 13 & $3 \%$ \\
\hline Disagreed & 6 & $2 \%$ \\
\hline Total & 388 & 100 \\
\hline
\end{tabular}

Source: Field survey november, 2015.

From the above table, 215 respondents representing 55\% strongly agreed that Mosquitoes bite causes malaria, whereas 154 respondents representing $40 \%$ agreed that Mosquitoes bite causes malaria. However, 13 respondents representing 3\% strongly disagreed also 6 respondent representing $2 \%$ disagreed Mosquitoes bite causes malaria

Question: Poor environmental sanitation causes malaria

Table 4. Response on whether Poor environmental sanitation causes malaria

\begin{tabular}{|l|l|l|}
\hline Responses & $\begin{array}{l}\text { No of } \\
\text { Respondent }\end{array}$ & $\begin{array}{l}\text { \% of } \\
\text { Respondent }\end{array}$ \\
\hline Strongly agreed & 236 & $61 \%$ \\
\hline Agreed & 92 & $24 \%$ \\
\hline Strongly & 33 & $8 \%$ \\
\hline
\end{tabular}


DOI: $10.21522 /$ TIJPH.2013.06.02.Art014

ISSN: $2520-3134$

\section{Source: field survey November, 2015}

\begin{tabular}{|l|l|l|}
\hline disagreed & & \\
\hline Agreed & 27 & $7 \%$ \\
\hline Total & 388 & $100 \%$ \\
\hline
\end{tabular}

Based on analysis presented on the above table 4, 236 respondent representing $61 \%$ strongly agreed that Poor environmental sanitation causes malaria, while 92 respondents representing $24 \%$ agreed that Poor environmental sanitation causes malaria, while 33 respondents representing $8 \%$ strongly disagreed and 27 respondents representing $7 \%$ disagreed also. Therefore, it can be denoting from the table that according to majority of respondents that poor environmental sanitation causes malaria.

Question: Poor nutrition system causes malaria

Table 5. Responses on whether Poor nutrition system causes malaria.

\begin{tabular}{|l|l|l|}
\hline $\begin{array}{l}\text { Respondent } \\
\text { response }\end{array}$ & frequency & percentage \\
\hline Strongly agreed & 118 & $30 \%$ \\
\hline Agreed & 193 & $50 \%$ \\
\hline $\begin{array}{l}\text { Strongly } \\
\text { Disagreed }\end{array}$ & 33 & $9 \%$ \\
\hline Disagreed & 44 & $11 \%$ \\
\hline Total & 388 & $100 \%$ \\
\hline
\end{tabular}

Source: Field survey november, 2015

From the above table, 118 of respondents representing 30\% strongly agreed that Poor nutrition system causes malaria, where 193 respondents representing 50\% agreed that Poor nutrition system causes malaria. However 33 respondents representing 9\% strongly disagreed that poor nutrition system causes malaria and 44 respondents representing $11 \%$ disagreed that. Poor nutrition system causes malaria this shows that greater percent of the respondents agreed that Poor nutrition system causes malaria.

Question: Poor drainage system causes malaria

Table 6. Response: on whether poor drainage system causes malaria

\begin{tabular}{|l|l|l|}
\hline $\begin{array}{l}\text { Respondent } \\
\text { response }\end{array}$ & frequency & percentage \\
\hline Strongly Agreed & 274 & $71 \%$ \\
\hline Agreed & 85 & $22 \%$ \\
\hline $\begin{array}{l}\text { Strongly } \\
\text { Disagreed }\end{array}$ & 29 & $7 \%$ \\
\hline Disagreed & - & - \\
\hline Total & 388 & $100 \%$ \\
\hline
\end{tabular}

Source: Field survey November, 2015

The table above indicates that 274 respondents representing $71 \%$ strongly agreed that Poor drainage system causes malaria, 85 respondents representing $22 \%$ agreed that Poor drainage system causes malaria, while 29 respondents representing 7\% strongly disagreed that Poor drainage system causes malaria. 
Question: Malaria can be prevented by avoiding mosquito bite

Table 7. Response on whether Malaria can be prevented by avoiding mosquito bite

\begin{tabular}{|l|l|l|}
\hline $\begin{array}{l}\text { Respondent } \\
\text { response }\end{array}$ & frequency & percentage \\
\hline Strongly Agreed & 268 & 69 \\
\hline Agreed & 94 & 24 \\
\hline $\begin{array}{l}\text { Strongly } \\
\text { Disagreed }\end{array}$ & 14 & 4 \\
\hline Disagreed & 12 & 3 \\
\hline Total & 388 & $100 \%$ \\
\hline
\end{tabular}

Source: Field survey November, 2015

The details of table 7 above shows that 248 respondents representing $69 \%$ are of the view that Malaria can be prevented by avoiding mosquito bite, 94 respondents representing $24 \%$ of the respondents maintained that. Malaria can be prevented by avoiding mosquito bite. Furthermore, 14 respondents representing $4 \%$ and the remaining 12 respondents representing $3 \%$ are of the view that Malaria can be prevented by avoiding mosquito bite. It can be seen from the above analysis that. Malaria can be prevented by avoiding mosquito bite.

Question: Malaria can be prevented by the use of intermittent preventive therapy (IPT)

Table 8. response on if Malaria can be prevented by the use of intermittent preventive therapy (IPT)

\begin{tabular}{|l|l|l|}
\hline $\begin{array}{l}\text { Respondent } \\
\text { response }\end{array}$ & frequency & percentage \\
\hline Strongly Agreed & 236 & 61 \\
\hline Agreed & 108 & 28 \\
\hline $\begin{array}{l}\text { Strongly } \\
\text { Disagreed }\end{array}$ & 34 & 9 \\
\hline Disagreed & 10 & 3 \\
\hline Total & 388 & $100 \%$ \\
\hline
\end{tabular}

Source: Field survey november, 2015.

The above table details the respondents view of whether Malaria can be prevented by the use of intermittent preventive therapy (IPT), 236 respondents representing 61\% strongly agreed and 108 respondents representing 28\% also agreed, whereas 34 respondents representing 9\% strongly disagreed that Malaria can be prevented intermittent preventive therapy (IPT) and 10 of the respondents disagreed that Malaria can be prevented by the use of intermittent preventive therapy (IPT).

Question: Malaria can be prevented by the use of insecticide treated mosquito nets

Table 9. Response on if malaria can be prevented by the use of insecticide treated mosquito nets

\begin{tabular}{|l|l|l|}
\hline $\begin{array}{l}\text { Respondent } \\
\text { response }\end{array}$ & frequency & percentage \\
\hline Strongly Agreed & 226 & $58 \%$ \\
\hline Agreed & 150 & $39 \%$ \\
\hline $\begin{array}{l}\text { Strongly } \\
\text { Disagreed }\end{array}$ & - & - \\
\hline Disagreed & 12 & $3 \%$ \\
\hline Total & 388 & $100 \%$ \\
\hline
\end{tabular}

Source: Field survey November, 2015 
DOI: $10.21522 /$ TIJPH.2013.06.02.Art014

ISSN: $2520-3134$

It can be seen from the above table that 226 respondents representing $61 \%$ are of the view that Malaria can be prevented by the use of insecticide treated mosquito nets, 150 respondents representing 39\% also agreed. Meanwhile, 12 of the respondents representing 3\% strongly disagreed that Malaria can be prevented by the use of insecticide treated mosquito nets

Question: Malaria can be prevented by health education and creation of awareness

Table 10. Responses on if malaria can be prevented by health education and creation of awareness

\begin{tabular}{|l|l|l|}
\hline $\begin{array}{l}\text { Respondent } \\
\text { response }\end{array}$ & frequency & percentage \\
\hline Strongly Agreed & 247 & $64 \%$ \\
\hline Agreed & 141 & $36 \%$ \\
\hline $\begin{array}{l}\text { Strongly } \\
\text { Disagreed }\end{array}$ & - & - \\
\hline Disagreed & - & - \\
\hline Total & 388 & $100 \%$ \\
\hline
\end{tabular}

Source: Field survey November, 2015

The above table disclosed that 247 respondents representing $64 \%$ are of the strongly agreed that Malaria can be prevented by Health Education and creation of awareness, 141 respondents representing 36\% are of the view that: Malaria can be prevented by Health Education and creation of awareness. From the above analysis it can be deduced that Malaria can be prevented by Health Education and creation of awareness.

Question: Malaria can be prevented through environmental sanitation

Table 11. Responses on if malaria can be prevented through environmental sanitation

\begin{tabular}{|l|l|l|}
\hline $\begin{array}{l}\text { Respondent } \\
\text { response }\end{array}$ & frequency & percentage \\
\hline Strongly Agreed & 220 & $57 \%$ \\
\hline Agreed & 114 & $29 \%$ \\
\hline $\begin{array}{l}\text { Strongly } \\
\text { Disagreed }\end{array}$ & 44 & $11 \%$ \\
\hline Disagreed & 10 & $3 \%$ \\
\hline Total & 388 & $100 \%$ \\
\hline
\end{tabular}

Source: Field survey November, 2015.

The above table shows that 220 of respondents representing $57 \%$ stated that Malaria can be prevented through Environmental sanitation. 114respondents representing 29\% also agreed. While 44 respondents representing $11 \%$ strongly disagreed that Malaria can be prevented through Environmental sanitation, also $10(3 \%)$ are of the view that Malaria cannot be prevented through Environmental sanitation.

Question: Malaria can be prevented with the use of insecticide treated net

Table 12. Responses on whether Malaria can be prevented with the use of insecticide treated net

\begin{tabular}{|l|l|l|}
\hline $\begin{array}{l}\text { Respondent } \\
\text { response }\end{array}$ & frequency & percentage \\
\hline Strongly Agreed & 229 & $59 \%$ \\
\hline Agreed & 67 & $17 \%$ \\
\hline Strongly Disagreed & 35 & $9 \%$ \\
\hline Disagreed & 57 & $15 \%$ \\
\hline Total & 388 & $100 \%$ \\
\hline
\end{tabular}

Source: Field survey November, 2015 


\section{Texila International Journal of Public Health \\ Volume 6, Issue 2, Jun 2018}

From the above table 12, it can be deduced, 229 Respondents representing 59\% strongly agreed that Malaria can be prevented with the use of insecticide treated net, while 67 Respondents representing $17 \%$ also agreed. Whereas 35 of the respondents representing $9 \%$ strongly disagreed and 57 Respondents representing $15 \%$ disagreed that Malaria can be prevented with the use of insecticide treated net.

Question: Majority of pregnant women use the hospital regularly for antenatal appointments and check-up.

Table 13. Responses on if Majority of pregnant women use the hospital regularly antenatal appointments and check-up

\begin{tabular}{|l|l|l|}
\hline $\begin{array}{l}\text { Respondent } \\
\text { response }\end{array}$ & frequency & percentage \\
\hline Strongly Agreed & 135 & $35 \%$ \\
\hline Agreed & 88 & $23 \%$ \\
\hline $\begin{array}{l}\text { Strongly } \\
\text { Disagreed }\end{array}$ & 79 & $20 \%$ \\
\hline Disagreed & 86 & $22 \%$ \\
\hline Total & 388 & $100 \%$ \\
\hline
\end{tabular}

Source: Field survey november, 2015.

It could be noticed from the above table that 135 out of 388 respondents were of the view that Majority of pregnant women use the hospital regularly for antenatal appointments and check-up, while 88 , representing $23 \%$ agreed, that Majority of pregnant women use the hospital regularly for antenatal appointments and check-up. 79 respondents representing 20\% strongly disagreed and 86 respondents maintained that Majority of pregnant women use the hospital regularly for antenatal appointments and check-up.

Question: Majority of pregnant women use hospital every time they sick

Table 14. Responses on whether majority of pregnant women use hospital every time they sick

\begin{tabular}{|l|l|l|}
\hline $\begin{array}{l}\text { Respondent } \\
\text { response }\end{array}$ & frequency & percentage \\
\hline Strongly Agreed & 177 & $46 \%$ \\
\hline Agreed & 144 & $37 \%$ \\
\hline $\begin{array}{l}\text { Strongly } \\
\text { Disagreed }\end{array}$ & 37 & $10 \%$ \\
\hline Disagreed & 30 & $7 \%$ \\
\hline Total & 388 & $100 \%$ \\
\hline
\end{tabular}

Source: Field survey november, 2015.

The above table shows that 177 of respondents representing $46 \%$ stated that Majority of pregnant women use hospital every time they sick. 144respondents representing 37\% also agreed. While 37 respondents representing 10\% strongly disagreed that Majority of pregnant women use hospital every time they sick, also $30(7 \%)$ are of the view that Majority of pregnant women use hospital every time they sick. 
DOI: $10.21522 /$ TIJPH.2013.06.02.Art014

ISSN: 2520-3134

Question: Majority of pregnant women do not use the hospital at all

Table 15. Responses on whether majority of pregnant women do not use the hospital at all

\begin{tabular}{|l|l|l|}
\hline $\begin{array}{l}\text { Respondent } \\
\text { response }\end{array}$ & frequency & percentage \\
\hline Strongly Agreed & 137 & $35 \%$ \\
\hline Agreed & 140 & $36 \%$ \\
\hline $\begin{array}{l}\text { Strongly } \\
\text { Disagreed }\end{array}$ & 61 & $16 \%$ \\
\hline Disagreed & 50 & $13 \%$ \\
\hline Total & 388 & $100 \%$ \\
\hline
\end{tabular}

Source: Field survey november, 2015

The above table shows that 137 of respondents representing 35\% stated that Majority of pregnant women do not use the hospital at all, 140 respondents representing 36\% also agreed. While 61 respondents representing $16 \%$ strongly disagreed that Majority of pregnant women do not use the hospital at all, also 50 and $13 \%$ are of the view that Majority of pregnant women do not use the hospital at all.

Question: Majority of pregnant women are unaware of the hospital and resource available before them.

Table16. Responses on whether majority of pregnant women are unaware of the hospital and resource available before them

\begin{tabular}{|l|l|l|}
\hline $\begin{array}{l}\text { Respondent } \\
\text { response }\end{array}$ & frequency & percentage \\
\hline Strongly Agreed & 200 & $52 \%$ \\
\hline Agreed & 118 & $30 \%$ \\
\hline $\begin{array}{l}\text { Strongly } \\
\text { Disagreed }\end{array}$ & 40 & $10 \%$ \\
\hline Disagreed & 30 & $8 \%$ \\
\hline Total & 388 & $100 \%$ \\
\hline
\end{tabular}

Source: Field survey november, 2015.

The above table shows that 200 of respondents representing 52\% stated that Majority of pregnant women are unaware of the hospital and resource available before them. 118respondents representing $30 \%$ also agreed. While 40 respondents representing $10 \%$ strongly disagreed that Majority of pregnant women are unaware of the hospital and resource available before them, also $30(8 \%)$ are of the view that Majority of pregnant women are unaware of the hospital and resource available before them.

\section{Test of hypotheses}

\section{Test of stated hypotheses}

The benchmark was also used as the population mean for this study. Stated hypotheses were statistically tested with the Z-statistic at $5 \%$ level of significance on a one-tailed test.

\section{Test of hypothesis one (Ho1)}

In other to test the hypothesis $\mathrm{Ho}_{1}$ : Pregnant women, attending antenatal clinic in Mile Four Hospital, Abakaliki in Ebonyi State were awared of malaria preventive measures. Therefore, there was a need to ascertain if pregnant women are aware of whether Malaria can be prevented by avoiding mosquito bite. 


\section{Texila International Journal of Public Health \\ Volume 6, Issue 2, Jun 2018}

Computed $\mathbf{Z}$ value of 37.5 is greater than the critical value $\left(Z_{0.05}\right)$ of 1.64 . The null hypothesis one $\left(\mathrm{Ha}_{1}\right)$ is therefore rejected to conclude that Pregnant women, attending antenatal clinic in Mile Four Hospital, Abakaliki in Ebonyi State are not aware of malaria preventive measures of malaria.

\section{Test of hypothesis two (Ho2)}

In the quest determine if pregnant women attending antenatal clinic in Mile Four Hospital, Abakaliki in Ebonyi State are utilizing malaria preventive measures to prevent themselves. The data in table 12 were used to compute the sample mean score and standard deviation for test of hypothesis one.

Computed $\mathrm{Z}$ value of -20.93is less than the critical value $\left(\mathrm{Z}_{0.05}\right)$ of 1.64 . The null hypothesis one $\left(\mathrm{Ho}_{1}\right)$ is therefore accepted to conclude that Pregnant women attending antenatal clinic in Mile Four Hospital, Abakaliki in Ebonyi State are utilizing malaria preventive measures to prevent themselves.

Table 19. Summaries of results of tested hypotheses

\begin{tabular}{|l|l|l|l|l|}
\hline Hypothesis & $\mathbf{Z}_{0.0}$ & $\mathbf{Z}$ & Comparison & Decision and Conclusion \\
\hline $\mathrm{Ha}_{1}$ & 1.64 & 37.5 & $37.5>1.64$ & $\begin{array}{l}\text { Reject } \mathrm{Ho}_{1} \text { and accept } \mathrm{Ho}_{1} \\
\text { that Pregnant women, } \\
\text { attending antenatal clinic in } \\
\text { Mile Four Hospital, } \\
\text { Abakaliki in Ebonyi State } \\
\text { are aware of malaria } \\
\text { preventive measures. }\end{array}$ \\
\hline $\mathrm{Ho}_{2}$ & 1.64 & - & $-20.93<$ & $\begin{array}{l}\text { Reject } \mathrm{Ho}_{2} \text { and accept } \mathrm{Ha}_{2} \\
\text { that Pregnant women } \\
\text { attending antenatal clinic in } \\
\text { Mile Four Hospital, } \\
\text { Abakaliki in Ebonyi State } \\
\text { are utilizing malaria } \\
\text { preventive measures to } \\
\text { prevent themselves. }\end{array}$ \\
\hline
\end{tabular}

Source: Researcher's computation (2016).

\section{Conclusion}

Based on the statistical analysis as presented on the tables above the summary can state as follows:

1. Pregnant women, attending antenatal clinic in Mile Four Hospital, Abakaliki in Ebonyi State are aware of malaria preventive measures.

2. Pregnant women attending antenatal clinic in Mile Four Hospital, Abakaliki in Ebonyi State are utilizing malaria preventive measures to prevent themselves.

\section{Analyses of the findings}

For purpose of analysis and easy presentation of the data, the data was presented with the aid of table percentage.

Table 2 disclosed that four hundred questionnaires were distributed to the respondents, out of the 400 questionnaires, 45 representing $12 \%$ were administered to the senior staffs and above, 51 questionnaires representing $13 \%$ were also distributed to junior staffs, and the entire questionnaire were returned completely. Moreover 154 questionnaires were also distributed to Pregnant Women attending antenatal from 0-5 months and 150 questionnaires were also distributed to Pregnant Women attending antenatal from 6- 9 months and 148 and 144 were returned respectively. Therefore, out of 400 questionnaires distributed, 388 questionnaires representing $98 \%$ of the total questionnaires were returned. Therefore, the returned questionnaire was used for the purpose of the study

In the quest to ascertain whether pregnant women are aware of the implications of mosquitoes bite to malaria infections. It was discovered from table 3, that 215 respondents representing 58\% strongly agreed that Mosquitoes bite causes malaria, whereas 134 respondents representing 36\% agreed that 
DOI: $10.21522 /$ TIJPH.2013.06.02.Art014

ISSN: $2520-3134$

Mosquitoes bite causes malaria. However, 13 respondents representing 4\% strongly disagreed also 6 respondent representing 2\% disagreed Mosquitoes bite causes malaria. Based on the above analysis, it can be seen that pregnant women are aware that mosquito bite causes malaria.

In other to ascertain the views of pregnant women on whether poor environmental sanitation causes malaria, table 4 detailed that. 236 respondent representing $61 \%$ strongly agreed that Poor environmental sanitation causes malaria, while 92 respondents representing $24 \%$ agreed that Poor environmental sanitation causes malaria, while 33 respondents representing $8 \%$ strongly disagreed and 27 respondents representing $7 \%$ disagreed also. Therefore, it can be denote from the table that most of respondents that poor environmental sanitation causes malaria.

There was a need know to if pregnant women were aware that poor nutrition system could cause malaria. Table 5 stated that, 118 of respondents representing 30\% strongly agreed that Poor nutrition system causes malaria, where 193 respondents representing 50\% agreed that Poor nutrition system causes malaria. However 33 respondents representing 9\% strongly disagreed that poor nutrition system causes malaria and 44 respondents representing $11 \%$ disagreed that. Poor nutrition system causes malaria this shows that greater percentage of the respondents agreed that Poor nutrition system causes malaria.

The process of the investigation, it was important to ascertain if poor drainage system causes malaria. Table 6 indicated that 274 respondents representing 71 percent strongly agreed that Poor drainage system causes malaria, 85 respondents representing 22 percent agreed that Poor drainage system causes malaria, while 29 respondents representing 7 percent strongly disagreed that Poor drainage system causes malaria. It can be denotes from the above that pregnant women are aware that Poor drainage causes malaria.

On the process of the investigation, the researcher tends to know if pregnant women were aware that Malaria can be prevented by avoiding mosquito bite. Table 7 showed that 248 respondents representing $69 \%$ are of the view that Malaria can be prevented by avoiding mosquito bite, 94 respondents representing $24 \%$ of the respondents maintained that. Malaria can be prevented by avoiding mosquito bite. Furthermore, 14 respondents representing $4 \%$ and the remaining 12 respondents representing 3 percent are of the view that Malaria can be prevented by avoiding mosquito bite. It can be seen from the above analysis that, malaria can be prevented by avoiding mosquito bites

In order to know if pregnant women are aware that malaria can be prevented by the use of intermittent preventive therapy (IPT). The above table 8 detailed that the respondents view of whether Malaria can be prevented by the use of intermittent preventive therapy (IPT), 236 respondents representing $61 \%$ strongly agreed and 108 respondents representing $28 \%$ also agreed, whereas 34 respondents representing 9\% strongly disagreed that Malaria can be prevented by the use of intermittent preventive therapy (IPT) and 10 of the respondents disagreed that Malaria can be prevented by the use of intermittent preventive therapy (IPT). The above is an indication that pregnant women are aware that malaria can be prevented by the use of intermittent preventive therapy (IPT).

The researcher tends to know if the pregnant women are aware that malaria can be prevented by the use of insecticide treated mosquito nets. Table 9 indicated that 226 respondents representing $61 \%$ are of the view that malaria can be prevented by the use of insecticide treated mosquito nets, 150 respondents representing 39\% also agreed. Meanwhile, 12 of the respondents representing 3\% strongly disagreed that malaria can be prevented by the use of insecticide treated mosquito nets.

The need aroused to ascertain if malaria can be prevented by Health Education and creation of awareness. Table 10 disclosed that 247 respondents representing $64 \%$ are of the strongly agreed that Malaria can be prevented by Health Education and creation of awareness, 141 respondents representing 36\% are of the view that: Malaria can be prevented by Health Education and creation of awareness. From the above analysis it can be deduced that Malaria can be prevented by Health Education and creation of awareness.

The researcher wanted to know if pregnant women were aware of Environmental sanitation as a preventive measure of Malaria. Table 11 showed that 220 of respondents representing $57 \%$ stated that Malaria can be prevented through Environmental sanitation. 114respondents representing 29\% also agreed. While 44 respondents representing $11 \%$ strongly disagreed that Malaria can be prevented 


\section{Texila International Journal of Public Health}

Volume 6, Issue 2, Jun 2018

through Environmental sanitation, also 10 (3\%) are of the view that Malaria cannot be prevented through Environmental sanitation.

The investigation disclosed that majority of pregnant women agreed that malaria can be prevented with the use of insecticide treated net, this can be seen in table 12, wehere 229 Respondents representing 59\% strongly agreed that Malaria can be prevented with the use of insecticide treated net, while 67 Respondents representing $17 \%$ also agreed. Whereas 35 Respondents representing 9\% strongly disagreed and 57 Respondents representing $15 \%$ disagreed that Malaria can be prevented with the use of insecticide treated net.

It could be noticed from table 13 that 135 out of 388 respondents were of the view that Majority of pregnant women use the hospital regularly for antenatal appointments and check-up. While 88, representing 23\% agreed that Majority of pregnant women use the hospital regularly for antenatal appointments and check-up. 79 respondents representing 20\% strongly disagreed and 86 respondents maintained that Majority of pregnant women use the hospital regularly for antenatal appointments and check-up.

Also in table 14, it was stated that 177 of respondents representing $46 \%$ stated that Majority of pregnant women use hospital every time they sick. 144respondents representing $37 \%$ also agreed. While 37 respondents representing 10\% strongly disagreed that Majority of pregnant women use hospital every time they sick, also $30(7 \%)$ and $30(8 \%)$ are of the view that Majority of pregnant women use hospital every time they sick.

Table 15 showed that 137 of respondents representing 35\% stated that Majority of pregnant women do not use the hospital at all, 140 respondents representing $36 \%$ also agreed. While 61 respondents representing $16 \%$ strongly disagreed that Majority of pregnant women do not use the hospital at all, also 50 and $13 \%$ are of the view that Majority of pregnant women do not use the hospital at all.

Table 16 also has it that 200 of respondents representing 52\% stated that Majority of pregnant women are unaware of the hospital and resource available before. 118respondents representing 30\% also agreed. While 40 respondents representing 10\% strongly disagreed that Malaria can be prevented through Environmental sanitation, also $30(8 \%)$ are of the view that Majority of pregnant women are unaware of the hospital and resource available before.

In the process of testing hypothesis "Ho " which stated that Pregnant women, attending antenatal clinic in Mile Four Hospital, Abakaliki in Ebonyi State are aware not of malaria preventive measures of malaria. The data in table 7 were used to compute the sample mean score and standard deviation and $Z$ statistics was used to test the hypothesis where $Z$ value of 37.5 is greater than the critical value $\left(\mathrm{Z}_{0.05}\right)$ of 1.64 . The null hypothesis one $\left(\mathrm{Ha}_{1}\right)$ is therefore rejected to conclude that Pregnant women, attending antenatal clinic in Mile Four Hospital, Abakaliki in Ebonyi State are not aware of malaria preventive measures of malaria.

Also data in table 12 were used to compute the sample mean score and standard deviation for test of hypothesis two.

Computing $Z$ value of -20.93is less than the critical value $\left(Z_{0.05}\right)$ of 1.64 . The null hypothesis one $\left(\mathrm{Ho}_{1}\right)$ is therefore accepted to conclude that Pregnant women attending antenatal clinic in Mile Four Hospital, Abakaliki in Ebonyi State are not utilizing malaria preventive measures to prevent themselves.

\section{Summary, conclusion and recommendations}

\section{Summary}

According to WHO 2010, Millions of pregnant women are exposed to malaria and thousands die every year through direct or indirect as a result of its consequences. It further disclosed that in all endemic areas, babies born to mothers infected with malaria parasites have a low birth weight and also at increased risk of death in infancy. Therefore, it is essential to treat pregnant women, who are infected with plasmodium parasites effectively. (White et al.; 2014).

It further stated that a quarter of all malaria cases in Africa occur in Nigeria. This magnitude of occurrence in this part of the world correlates with poverty, ignorant and social deprivations in the community. The problem of malaria in pregnancy possesses a substantial risk to the mother, her foetus and the neonates. It significantly contributes to anaemia in pregnancy as the parasitmia appear 


\section{DOI: $10.21522 /$ TIJPH.2013.06.02.Art014}

\section{ISSN: 2520-3134}

greater in the second trimester and may persist into the early post-partum period, increasing the low birth weight and is associated with preterm deliveries, still birth and perinatal mortality in Nigeria (Centre for Disease and Prevention, 2009)

Furthermore, malaria is responsible for $25 \%$ of infant mortality and $30 \%$ of all childhood death and that is why Nigeria is a signatory to the Abuja declaration that set as one of the Abuja targets that $60 \%$ of pregnant women should receive intermittent preventive treatment drug during pregnancy by end of 2005 (WHO, 2014). Despite the effective launching of the roll back malaria since year 2001 in most African countries. Pregnant women have a higher risk than the non - pregnant ones to be infected with malaria and they are at increased risk of adverse events such as ammonia, risk of miscarriage, still birth, preterm delivery, total growth, restriction and even death.

It should be recalled that, Most Ebonyi people including women and highly involve in agricultural activities, which encourage the breeding of mosquitoes and consequently malaria infection is not an over statement to state that malaria has numerous negative outcomes which may include financial involvement translating into poor standard of living, hospital visitations as well as low productivity and loss of income (Kayentao et al.; 2012).

Based on the negative impact of malaria to pregnant women, this research is aimed at conducting an investigation to ascertain the extent of awareness and utilization of malaria preventive measures to pregnant women, attending antenatal clinic in Mile Four Hospital, Abakaliki in Ebonyi State. The population of the study was all the staff of antenatal section and pregnant women attending antenatal in Mile Four Hospital Abakaliki. The researcher adopted Taro Yamani sampling technique to get the representatives of the entire population.

The finding disclosed that pregnant women, attending antenatal clinic in Mile Four Hospital, Abakaliki

in Ebonyi State are aware of malaria preventive measures, and also that pregnant women attending antenatal clinic in Mile Four Hospital, Abakaliki in Ebonyi State are utilizing malaria preventive measures to prevent them.

\section{Conclusion}

In the process of this study, it was concluded that those pregnant women are aware that mosquito bite causes malaria, that poor environmental sanitation causes malaria, the respondents agreed that Poor nutrition causes malaria, that majority of pregnant women are aware that Poor drainage system causes malaria.

In quest to ascertain if the pregnant women are aware of preventive measure available to prevent malaria, the researcher also concluded that: most of the pregnant women were of the view that malaria can be prevented by avoiding mosquito bite, that the pregnant women are aware that malaria can be prevented with the use of intermittent preventive therapy (IPT), that they are also aware that Malaria can be prevented with the use of insecticide treated mosquito nets, that the pregnant women were also aware that Malaria can be prevented by Health Education and creation of awareness, pregnant women are of the view that Malaria cannot be prevented through Environmental sanitation.

Majority of pregnant women do not use the hospital regularly for antenatal appointments and check-up, that Majority of pregnant women do not use hospital every time they sick, that Majority of pregnant women do not use the hospital at all and that Majority of pregnant women are unaware of the hospital and resource available before them.

Based on the tested hypothesis, the researcher also concluded that, Pregnant women, attending antenatal clinic in Mile Four Hospital, Abakaliki in Ebonyi State are aware of malaria preventive measures and that Pregnant women attending antenatal clinic in Mile Four Hospital, Abakaliki in Ebonyi State are utilizing malaria preventive measures to prevent themselves.

\section{Recommendations}

Having gone through the related literature, analysis of respondent's views on the subject matter and base on the results and findings of this work, the following recommendations were made by the researcher to address the challenges found in the cause of the study that have been militating against the awareness and utilization of malaria preventive measures to pregnant women attending antenatal 


\section{Texila International Journal of Public Health \\ Volume 6, Issue 2, Jun 2018}

clinic in Mile Four Hospital, Abakaliki in Ebonyi State. The researcher recommends as follows: That awareness campaign should be drawn to rural areas so that Pregnant women should be educate on high risk involve in malaria infestation, because if they are fully aware of the risk, Majority of pregnant women will be using the hospital regularly for antenatal appointments and check-up, Most of them will use hospital every time they sick and thereby become aware of the hospital and resource available before them reducing the level of miscarriage, low birth weight, still birth and maternal death.

Awareness campaign should be drawn to rural areas so that pregnant women should know the risk associated with the activities that will encourage the breeding of mosquitoes, mosquito bite, poor environmental sanitation, Poor nutrition, and Poor drainage system causes malaria.

pregnant women in rural areas will also be educate on the prevention of malaria through the use of insecticide treated mosquito nets, intermittent preventive therapy (IPT), Environmental sanitation and by avoiding mosquito bite.

\section{Acknowledgment}

I thank God for his faithfulness, assistance and strength towards me and also my friends who contributed greatly on this work.

\section{References}

[1].Ahmed, R., Levy, E.I., Maratina, S.S, et al; (2010). Performance of four HRP-2/pLDH combination rapid diagnostic tests and field microscopy as screening tests for malaria in pregnancy in Indonesia: a cross-sectional study.

[2].Bhatia, R., Rastogi, R.M. and Ortega, L. (2013). Malaria successes and challenges in Asia. J Vector Borne Dis.

[3].Bugvi, S.M. and Ahmed, N. (2015). Congenital Malaria: ARare Entity. J Coll Physicians Surg Pak.

[4].Centers for Disease Control and Prevention, (2009).Intermittent Preventive Treatment of Malaria for Pregnant Women (IPTp).

[5].Chukwuochaetal, (2010). The World Malaria Report Malaria: guidance, data and analysis.

[6].David, Sinclair. (2012). Malaria and Pregnancy: A Global Health Perspective.

[7].Ducarme, G., Thuillier, C. and Wernet, A. et al. (2008). Malaria in pregnant woman masquerading as help syndrome.

[8].Kayentao, K., Garner, P. and van Eijk, A.M., et al; (2012). Intermittent preventive therapy for malaria during pregnancy using 2 vs 3 or more doses of sulfadoxine-pyrimethamine and risk of low birth weight in Africa: systematic review and meta-analysis.

[9].Minnesola, (2010). Mental Health Care Delivery NetworkMalaria facts.http://www.cdc.gov/malaria/facts.htm. Updated.

[10]. White, N.J. and Breman, J.G. (2014). Malaria. In: Fauci AS, Braunwald E, Kasper DL, et al., editors. Harrison's Principles of Internal Medicine. 17th ed. New York: McGraw-Hill.

[11]. Williams, L.L., Jr (2016). Malaria eradication in the United States. Am J Public Health Nations Health.

[12]. World Health Organization, authors. (2003). Guidelines for the Treatment of Malaria. Geneva: World Health Organization.

[13]. World Health Organization (2010). Web site, authors. Global Malaria Programme: pregnant women and infants.

[14]. World health organization (2013). The World Malaria Report, summarize information received from malaria-endemic countries and other sources, and updates the analyses.

[15]. World Health Organization (2014). Web site, authors. Global Malaria Programme: pregnant women and infants. 